\title{
Private and Public Investment Linkages: Some Evidence Using Sectoral Level Data
}

\author{
Umbreen Zahra ${ }^{1}$, Hajra Ihsan ${ }^{2}$ and Abdul Rashid ${ }^{3}$
}

\begin{abstract}
This study empirically investigates the relationship between public and private investment in Pakistan at the aggregate and sectoral level, including the sectors of Agriculture, Manufacturing, Finance, Construction, Transport \& Communication and Mining \& Quarrying. For this purpose, annual time series data is utilized from 1971 to 2019 except for the Agriculture sector covering the period of 1981-2019 as data for previous years is not available from any published sources. Multivariate co-integration approach and ECM are employed to empirically analyze the existence of long-run and short-run association among public and private investment. The results indicate a long run complementary type relationship of public investment with private investment at both the aggregate and sectoral level except for the Finance sector. The short-run analysis supports this long-run positive association at an aggregate level and four sectors, excluding Transport \& Communication and Agriculture sector where the results were insignificant. Our results and generally declining share of public investment highlight that the government is playing its role as an "enabler" (or facilitator) of private investment in terms of association between public and private investment.
\end{abstract}

Keywords: Public Investment and Private Investment; Crowding in; Crowding out.

JEL Classification: C50, E22, E62

\section{Introduction}

According to economic theory, investment is a factor of production, so it can increase production and, depending on whether marginal returns are decreasing or not it can affect the level or rate of growth of output (Fournier, 2016). In general, the higher the investment rate, the higher the production level (Solow, 1956). In the Solow model, investment does not imply a permanent growth effect due to diminishing returns. Besides the effect on the level of economic activity (GDP), a key conclusion in the endogenous growth literature with a constant or increasing

\footnotetext{
${ }^{1} \mathrm{PhD}$ Scholar, International Institute of Islamic Economics, International Islamic University Islamabad.

${ }^{2}$ Assistant Professor, International Institute of Islamic Economics, International Islamic University Islamabad.

${ }^{3}$ Director General, International Institute of Islamic Economics, International Islamic University Islamabad.

Corresponding author's Email: hajra.ihsan@iiu.edu.pk
} 
rate of return to scale is that the accumulation of physical and human capital plays a vital role in long-term growth. (Lucas Jr, 1988; Romer, 1990).

As mentioned by one of the pioneer studies on public investment $(\mathrm{P})$, Aschauer (1989), the effect of public investment on growth is most likely positive and depends on the extent to which private investment is crowded in or crowded out. If public investment complements the private capital (e.g. through roads connecting enterprises, reducing the cost of transportation, facilitating the flow of goods and services), increased public investment can stimulate private investment (Aschauer, 1989; Blejer \& Khan, 1984; Munnell, 1992; Ramirez, 1994). This relates to situations where the private rate of return is lower than the social rate of return, for example as Arrow (1962) examined it in the case of knowledge production, considered to be a public good in general and that can benefit all.

Likewise, another study by Romer (1986) shows that state intervention can lead to welfare benefits with positive externalities. In other words, the rate of return on investment expected by the private sector reflects only the private rate of return, so without government intervention, the investment ratio will be lower than the social optimum: indicating a role for public investment. On the other hand, if private and public capital are substitutes, increasing public capital may reduce private investment (Al-Majali, 2018; Bahal, Raissi, \& Tulin, 2018; Mahmoudzadeh, Sadeghi, \& Sadeghi, 2017; Morrissey \& Udomkerdmongkol, 2012; Phetsavong \& Ichihashi, 2012). The crowding-out may be partial, therefore overall investment still increases. If one unit of public investment replaces the one unit of private investment, total investment remains unchanged. This can occur when public investment is focused on certain functions that do not increase the return on private investment (for example, investments in public companies in sectors with no externalities). In this scenario of crowding out, growth effects can even be negative if public investment is less effective than private investment.

There are four types of public investment: infrastructure, human capital, $\mathrm{R}$ $\&$ D investment, and business investment. The gross fixed capital formation consists of physical assets, intangible assets such as software, and tangible fixed assets including military spending to support civilians such as hospitals. On the other hand, "purchasing military weapons and their support systems" is not part of gross fixed capital formation. In the literature, a number of channels linking public investment spending to private investment have been identified [e.g., (Aschauer, 1989; Blejer \& Khan, 1984; Buiter, 1977; Erenburg \& Wohar, 1995; Ramirez, 1994) Barth and Cord, 1980; Primarily, as already mentioned public investment can lead to more output which in turn generates more physical and financial resources 
in the economy. Additionally, public spending on infrastructure such as roads, railroads, highways, sewage, education, and power plants, and water systems often lowers private-sector costs. Such type of infrastructure investment by the public sector complements private investment and improves private capital productivity. However, in some cases, the impact of public investment on private investment can be negative. For example, if the public and private sectors compete for the same resources of the economy, the availability of credit to the private sector is diminished while the cost of financing private investment increases. It can crowd out the investment in the private sector. Subsidized state-owned economic enterprises are often financed through the printing press, external debts and deficit spending (Erden \& Holcombe, 2006). In a situation of high budget deficit, the financing of public investment will lead to less credit availability and/or higher interest rates which in turn can crowd out the private sector from profitable investment opportunities. Further, public investment can replace private investment when both produce those goods and services that compete directly in the market, specifically a case when government subsidizes such public production. As mentioned, different offsetting and competing roles are played by public investment in terms of its impact on investment in the private sector therefore, the net impact of public investment on private investment in general and at the sectoral level is an empirical question.

Government can finance its expenditures through different ways from domestic sources like financing through issuing government bonds, tax collection, and printing of new money (Bell, 2000). Government investment expenditures financed through open market operations can diminish the loanable funds reserves available to the private sector for investment purposes (Diamond, 1965; Emran \& Farazi, 2009; Hyder \& Qayyum, 2001; Looney, 1995; Mitra, 2006; Shafik, 1992). If public expenditures are financed by taxes, then higher taxes drop the after-tax returns to PRI. Moreover, it will reduce disposable income and consumption, which in turn adversely affects investment by the private sector. As already mentioned, PI expenditures may adversely affect PRI by decreasing the availability of saving for PRI. Thus, this mode of financing may also crowd out the PRI from the home capital market (David \& Scadding, 1974; Seater, 1993).

In general, the available empirical evidence also shows mixed results as some studies show crowding in while others indicate crowding out of private 
investment ${ }^{4}$. In the case of Pakistan, a number of researchers analyze the effect of PI on PRI, e.g., Hussain, Muhammad, Akram, and Lal (2009), Saeed, Hyder, Ali, and Ahmad (2006), Rashid (2006), Naqvi (2002), Hyder and Qayyum (2001), Looney (1995) reported a crowding-in effect of public capital formation. However, Saghir and Khan (2012), Hyder and Qayyum (2001), Haque and Montiel (1993) found the crowding-out effect in the case of Pakistan.

When we look at the previous international studies, we observe that most of them have focused on the linkages of public and private investment at the aggregate level. See, for example, Canh and Phong (2018), Dreger and Reimers (2015), Foye (2014), Gjini and Kukeli (2012), Furceri and Sousa (2011), Hatano (2010), Erden and Holcombe (2006), Mitra (2006), Naqvi (2002), Voss (2002), Laopodis (2001), Erenburg (1993), Serven (1996), Bajo-Rubio and Sosvilla-Rivero (1993), and Haque and Montiel (1993). Similarly, most of the studies in Pakistan such as Fatima (2012), Saghir and Khan (2012), Hussain et al. (2009), Rashid (2006), Naqvi (2002), and Hyder and Qayyum (2001) have also worked on the aggregate level. Yet a few studies such as Ahmad and Qayyum (2008), Saeed et al. (2006) and Looney (1995) have used sector level data but they analyzed only one or two sectors. Therefore, there is still a gap in the literature which required to be filled by conducting a detailed research on the linkages of public and private investment at disaggregates level in Pakistan because the effect can differ across different sectors depending upon the positive/negative externalities generated by public investment in that sector. Moreover, the sectoral level analysis will be more informative and will provide more clear insight to the policy maker as focus of public sector should be on the sectors with positive externalities indicating complementary type relationship between public and private investment. Therefore, this study comprising analysis on both aggregate as well as sectoral level will be more informative.

This study mainly tries to analyze the impact of public investment on private investment at an aggregate level and at the sectoral level in the case of Pakistan because the relationship may vary across sectors depending upon the extent and nature of externalities, size of public investment, and the difference between private and social rate of return due to government intervention. Further, we will examine

${ }^{4}$ For examples the studies showing crowding in are Rashid (2006), Serven (1996), Erenburg (1993), Aschauer (1989), and Blejer and Khan (1984). Similarly, those studies that show crowding out are Gjini and Kukeli (2012), Cavallo and Daude (2011), Furceri and Sousa (2011) and Voss (2002). 
whether there are differences in this relationship over the short and long run at the aggregate and sectoral levels.

Six sectors are considered in this study depending upon the availability of annual data. The aggregate and sectoral level data on public and private gross fixed capital formation is taken from Pakistan Economic Survey (2019-20 and earlier issues). The included six sectors are: Agriculture, Manufacturing, Finance, Construction, Transport \& Communication and Mining \& Quarrying. The period considered in the study is from 1971-2019 except for the Agriculture sector covering the period of 1981-2019 as data for previous years is not available from any published sources. On average these six sectors cover 75 percent of total private investment and 60 percent of aggregate public investment over the spanned period. ${ }^{5}$ Considering the preliminary findings of stationarity, Johansen test of cointegration, etc., the techniques of VECM is utilized for overall and sectoral analysis.

The rest of the paper is structured into five sections. Section 2 presents the review of literature and section 3 explains the estimation methodology, data, variable definitions and data sources. Section 4 reports empirical results and discussions. Section 5 briefly presents conclusions and some policy implications.

\section{Literature Review}

On the theoretical side, a number of models exist on investment behavior that relate to developing countries. Due to certain restrictions, the traditional models no longer apply to developing countries. The conventional accelerator model may be best suited for investment behavior in developed countries, but the existence of liquidity constraints and lack of perfect capital markets make it is less applicable to developing countries. Gjini and Kukeli (2012) highlighted the theoretical linkages between public and private investment and important theories of investment. These theories are Expected Profit Theory, Marginal Efficiency Theory, Accelerator Theory, Neo-classical Theory, Ricardian Equivalence Theory and Neoliberal Approach.

According to marginal efficiency theory, investment should be undertaken when the marginal efficiency of additional investment is greater than the cost of financing. If the cost of financing is higher than its marginal efficiency (i.e., interest rates are higher than the return on investment) then it would be more profitable to lend the available funds at the prevailing interest rate, rather than investing for productive purposes. Thus, the relationship between public and private investment can be established under the marginal efficiency theory of investment. Specifically,

\footnotetext{
${ }^{5}$ Further details about data are given in data and variable section.
} 
public investment affects private investment through the interest rate channel. In particular, increases in government investment may lead to a decrease in the available funds, as a result, this channel pushes interest rates up. Thus, private investment decreases.

The Acceleration principle proposed by Clark (1917) states that the "desired level of capital stock is proportional to output". Thus, investment is proportional to the output growth in all the periods. Government and private investment increase as stock of capital increases which enhances further growth via the accelerator effect.

The flexible accelerator model was developed by Koyck (1954). This model shows the relationship between investment and output, "the greater the gap between desired capital stock and existing capital stock, the higher would be the rate of investment". The hypothesis of this model is based on investors plan to minimize the gap between actual capital stock and desired capital stock. Two channels are developed in this context. The first channel is capital accumulation, where, the output of the economy increase due to an increase in government investment. This channel leads to an increase in private investment. The second channel refers to the cost of capital when the government investment increases it leads to an increase in the cost of borrowing for private investors. As a result, private investment and capital stock will decrease.

Jorgenson (1971) developed the Neo-Classical theory and it is a modified version of the flexible accelerator model. According to this approach, the desired capital stock is proportionate to the output and cost of capital which in turn depends on the interest rate, tax structure, and price of capital goods. The key element of the investment model is the interest rate so it adversely affects private investment. NeoClassicals believe that an increase in public investment decreases the amount of funds available for private investors because competition will lead to an increase in the interest rate and decrease in private investment. Thus, government financing pushes the interest rate up and private investment decreases.

First time Keynes (1936) considered investment as an independent variable. Keynes's theory of investment has two aspects. First, if the expected future profit rate is larger than a great chance of investment because investment is feasible. The second aspect is linked with a higher rate of interest which is associated with the relationship of public and private investment. Interest rate rises due to an increase in public investment, which means that the cost of borrowing is high for private investors hence adversely affects private investment. However, Keynesians claim that the positive effect of an increase in public investment is greater due to 
multiplier effects than the negative effect in terms of reduction in private investment. Given this, the output of an economy increases with an increase in public investment. The two opinions have been made about crowding out, such as the full crowding out and partial crowding out. The full crowding out occurs only in exceptional cases when the negative effects of reduced private investment cancel out the positive effect of increases in public investment and thus, the output of the economy remains the same.

Ricardian Equivalence theory was developed in the $19^{\text {th }}$ century by David Ricardo. The main idea behind this theory is, when a government tries to boost the demand by increasing government expenditures through debt financing, the demand remains the same because the people are willing to save their excessive money to pay the increase in future taxes to pay off the debt. Ricardian equivalence theory is contradictory to Keynes's theory of investment. The major criticism of Ricardian equivalence is on its unrealistic assumptions ${ }^{6}$. Ricardo gives justification for the crowding-out effect. As stated by him, government expenditures need to be financed, at present or in the future through taxes. In the future the taxes will be high that will lead to a decrease in disposable income. Thus, with the decrease of disposable income people will have less money to invest. This will adversely affect private investment (Xu \& Yan, 2014).

The latest approach which describes the importance of financial expansion and the rate of interest in the progress of economic development is called the Neoliberal approach. The advocates of this approach McKinnon and Shaw (1973) reported that the real interest rate and investment might have a positive relationship because a higher real interest leads to increase savings. When saving is high the availability of funds for private investment is high. This is known as MacKinnon and Shaw's hypothesis. This hypothesis is established on the assumption of limitations in the volume of financial resources instead of the cost of financing. In the context of developing countries, public investment plays an important role in economic growth.

The neoliberal approach has established a positive relationship between the real rate of interest and investment, on the other hand, this is contradictory with the Neo-classical framework. A higher real rate of interest may decrease the investment but implicit (realized) investment may increase due to an increase in the availability of funds. This phenomenon is known as the "Conduit effect".

\footnotetext{
6 "The assumption of (a) Existence of perfect capital markets. (b) The individual has ability to borrow and save at any time. (c) The individual is willing to save for increase in unseen future taxes."
} 
In sum, the Marginal theory of investment and Neo-classical theory established the negative relationship between public investment and private investment. The availability of funds is limited. The competition for attaining funds increases interest rate and as a result, private investment falls. Moreover, the Flexible accelerator theory and Keynes theory also suggest a negative relationship between public and private investment due to the cost of borrowings. However, the Accelerator and Flexible accelerator theory suggested a positive relationship between public and private investment due to the accumulation of capital stock. The neoliberal approach is contradictory with the Neo-classical theory of investment because the Neoliberal approach explained the positive relationship between an increase in interest rate and investment through saving channel. But the Neo-classical approach supports the crowding-out effect.

There is a huge amount of empirical literature that has analyzed the influence of PI on PRI like Canh and Phong (2018), Dreger and Reimers (2015), Foye (2014), Gjini and Kukeli (2012), Erden and Holcombe (2006), Naqvi (2002), Hyder and Qayyum (2001), and Ghura and Goodwin (2000) have investigated the determinants of investment in cross-national data taken from Asia, Sub-Saharan Africa, and Latin America. In the sample of 31 developing countries by considering, PRI is motivated by raises in PI, improvements in financial intermediation, a decrease in credit for the public sector and interest rate. Moreover, Naqvi (2002) and Hyder and Qayyum (2001) have analyzed the linkage between the PI and PRI of Pakistan at the aggregate level. The capital formation of the public sector has shown a significant positive impact on PRI. Hyder and Qayyum (2001) have tested the crowding-out hypothesis through the error correction model (ECM). The results confirmed the positive relation between PI and PRI. Rashid (2006) examined the association among PI and PRI in Pakistan at the aggregate level by using the Johansen cointegration approach, impulse response functions and variance decompositions. The empirical results suggested the complementary or positive relationship based on the ECM.

Further, Canh and Phong (2018) have investigated the influence of PI on PRI and economic growth for 18 developing countries from a period of (19952015). In this study, they concluded that PI has a direct effect on PRI in the long run. Moreover, Foye (2014), and Dreger and Reimers (2015) both have also supported the crowding-in effect of PI on PRI.

Gjini and Kukeli (2012) investigated the PI and PRI linkages for 11 Eastern Economies, comprising of six developing and five developed economies. The analysis confirmed direct linkages between PI and PRI. The marginal outcome of 
PI on PRI remained positive and started to decrease when the economy moved from developing to the more developed economy. The inadequate financial resources for PRI have appeared more relevant to developing countries. Increasing the availability of credit has a direct effect on PRI (Aschauer, 1989; Cavallo \& Daude, 2011; Erden \& Holcombe, 2005; Ghura \& Goodwin, 2000; Ramirez, 1994; Wai \& Wong, 1982).

Furceri and Sousa (2011) analyzed 145 countries and their findings suggested that government spending inversely affected both PRI and private consumption. The government spending effects on consumption and investment have seemed to rely on different factors like democracy, corruption, political stability, income and interest rate. Cavallo and Daude (2011) have investigated the association between PI and PRI covering the data of 116 developing countries. Their findings have shown that on average PI crowded out the PRI. Saghir and Khan (2012) have conducted a study on Pakistan's economy. They concluded that government investment negatively affected PRI. The effect of PI on PRI at the aggregate level as well as disaggregate level is examined by Pereira (2001) and Saeed et al. (2006). Specifically, Pereira (2001) estimated the VAR model with the variables like private gross domestic product, PRI, PI and private employment for US economy and PI and PRI were further disaggregated into highways, education, electric and gas facilities, sewage, water supply, hospital building and development structure. On average level, he found that PI had crowded in effect on PRI. At disaggregate level the crowding in effect was strong on industrial equipment and transportation equipment.

Kollamparambil and Nicolaou (2011) analyzed the South African economy. They found that the association among PI \& PRI and GDP. They observed the direct effect of PI on GDP. However, they found the indirect effect of PI on PRI. Hence, PI decreased mainly in the transport, equipment, and machinery sectors. In contrast, PI increased in construction. Fujii, Hiraga, and Kozuka (2013) examined the effect of PI on PRI at the sector level and found that the effects on sectoral capital investments varied from industry to industry because of different policy implications. Some sectors have shown a negative effect of PI on PRI due to misallocation of resources but on the whole, crowding in effect dominated.

All of the above literature shows inconclusive results about the nature of association between PI and PRI at both theoretical level and empirical level (at national as well as international level). However, it would be interesting to analyze the nature of this relationship at the sectoral level in Pakistan to investigate similarities/dissimilarities in this association. 


\section{Methodology and Data}

Pesaran and Smith (1998) suggested the Vector Error Correction Model (VECM) to explore the association between PI and PRI.

$$
\begin{aligned}
& \Delta y_{t}=\sum_{i=1}^{p-1} \Gamma_{i y} \Delta z_{t-i}+\prod_{y} \Delta z_{t-1}+\lambda_{y} \Psi_{t}+\alpha_{1 y} t+\alpha_{0 y}+\xi_{t} \\
& \mathrm{t}=1,2,3, \ldots \mathrm{T} \\
& \Delta x_{t}=a_{0 x} \sum_{i=1}^{p-1} \Gamma_{i x} \Delta x_{t-i}+\zeta_{t}
\end{aligned}
$$

$y_{t}=$ vector $(2 \times 1)$ of endogenous variable at I (1) including fixed PI and fixed PRI.

$x_{t}=$ vector of $(2 \times 1)$ exogenous variable at I (1) including real interest rate, GDP and percentage of debt to GDP.

$z_{t}=\left(y^{\prime}, x^{\prime}\right)^{\prime}$

$\Psi_{t}=$ vector of exogenous variable at I (0) which are not included in the intercept.

$\mathrm{t}=$ time trend

$\Delta=$ difference operator

$\alpha_{0 y}=$ represent intercept

$\xi_{t}$ and $\zeta_{t}=$ disturbance terms

This model assumes that a response from $\Delta y_{t}$ to $\Delta x_{t}$, but no response in level form. Therefore, $\Delta \boldsymbol{x}_{\boldsymbol{t}}$ is given in equation (2). Two variables are taken as endogenous for example, fixed PI and PRI variables and these three are considered as exogenous including interest rate, output, percentage share of debt to GDP.

\subsection{Data, Variable Definition and Data Sources:}

To estimate the impact of PI on PRI at a sectoral level, this study uses the 49 years annual data from 1971 to 2019 for six sectors because the data for this period is available for only six sectors. Data on fixed PI, fixed PRI at current prices and Gross Domestic Product (GDP) were collected from various issues of the Economic Survey of Pakistan, and data on the interest rate was collected from International Financial Statistics (IFS). 
Private and Public Investment Linkages:

Some Evidence Using Sectoral Level Data

Table 3.1: Variables Description

\begin{tabular}{|c|c|}
\hline Variable & Description \\
\hline GDP & $\begin{array}{l}\text { GDP is used as a control variable which shows the market value of all finished goods and } \\
\text { services which are produced in a country within the year. We obtained the nominal GDP of } \\
\text { Pakistan from the Economic Survey of Pakistan. It is measured in Millions of Rupees. }\end{array}$ \\
\hline Interest rate & $\begin{array}{l}\text { The percentage call money rate is used as another control variable in the estimation process. } \\
\text { It is taken from International Financial Statics. }\end{array}$ \\
\hline Fixed PI & $\begin{array}{l}\text { The gross fixed public capital formation at current market prices is used as an endogenous } \\
\text { variable in our estimation process at both aggregate as well as at sectoral level. It is measured } \\
\text { in Millions of Rupees. This information is obtained from various issues of Economic Survey } \\
\text { of Pakistan, }\end{array}$ \\
\hline Fixed PRI & $\begin{array}{l}\text { The gross fixed private capital formation at current market prices is used as an endogenous } \\
\text { variable in our estimation process at both aggregate and sectoral level. It is measured in } \\
\text { Millions of Rupees. Data is gathered from various issues of the Economic Survey of Pakistan. }\end{array}$ \\
\hline Debt-to-GDP & $\begin{array}{l}\text { The percentage share of total debt (including both internal and external debt) to GDP is used } \\
\text { as another control variable in the analysis. Data is gathered from various issues of the } \\
\text { Economic Survey of Pakistan }\end{array}$ \\
\hline
\end{tabular}

The following figures indicate the changing behavior of percentage share of public and private investment relative to total investment of Pakistan at an aggregate level and the similar percentage shares of public and private investment relative to the relevant total sectoral investment in each of the six sectors over the sampled time period ${ }^{7}$. Figure 3.1 shows that as compared to the 1970 s, where the share of public investment shows an increasing trend, for the rest of the period it shows a decreasing trend in general with little fluctuations. Reverse is the case with a share of private investment. The aggregate private investment varies between the minimum value of $36.3 \%$ in 1976 to the maximum of $93 \%$ in 2010 and likewise, public investment from $7 \%$ in 2010 to $63.7 \%$. At present, the share of private investment is $91.7 \%$ and that of public investment is $8.3 \%$, while at the start of the sampled period (1971) these shares were 57.9 and 42.1 percent, respectively. So, in general, private investment shows a general increasing trend after 1976 and public investment a decreasing one.

\footnotetext{
${ }^{7}$ The figures showing public and private investment in logarithmic format aggregate and sectoral level are given in the Appendix.
} 
Figure 3.1: The Share of Public and Private investment at Aggregate Level

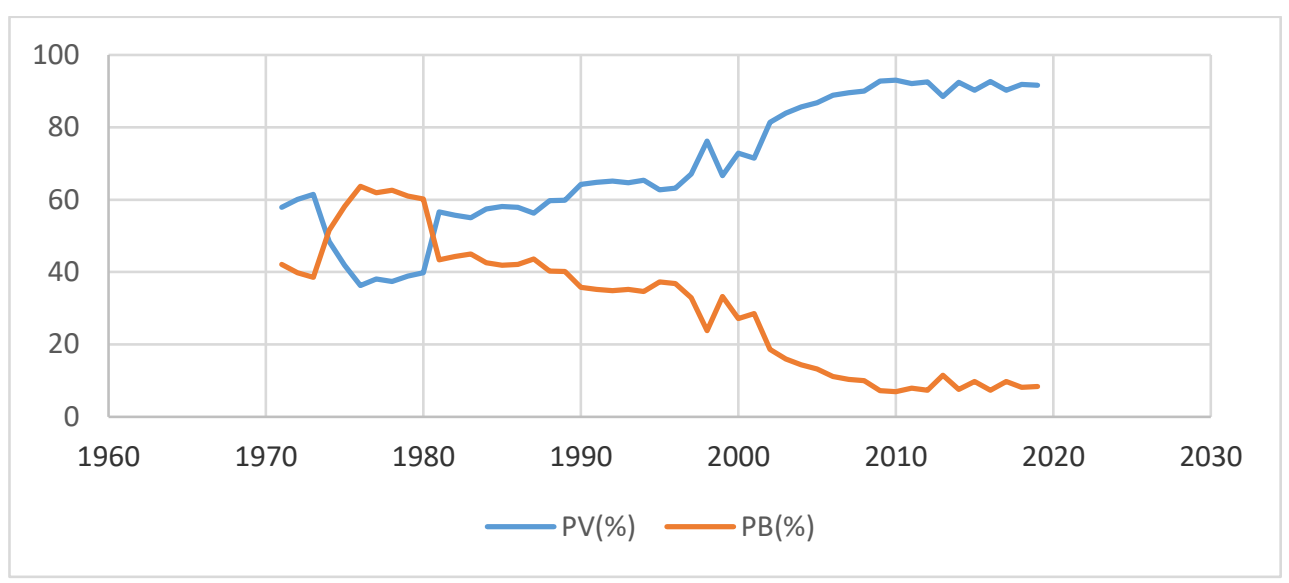

Figure 3.2: The Share of Public and Private Investment in Mining and Quarrying

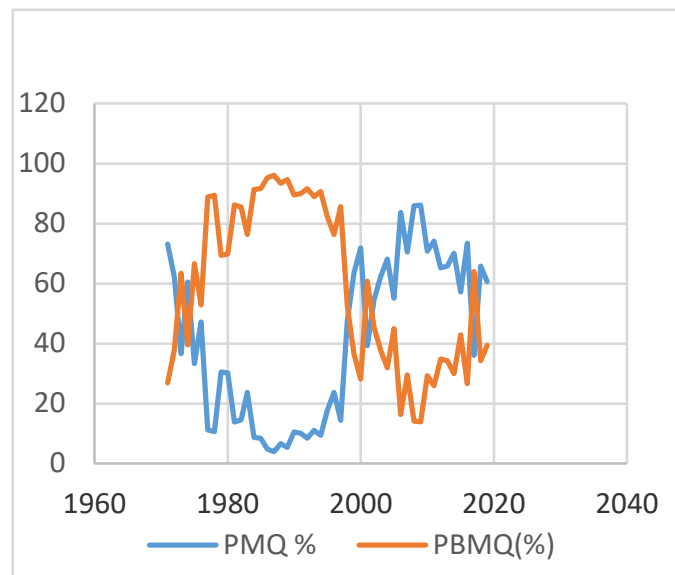

Figure 3.3: The Share of Public and Private Investment in Transport and Communication

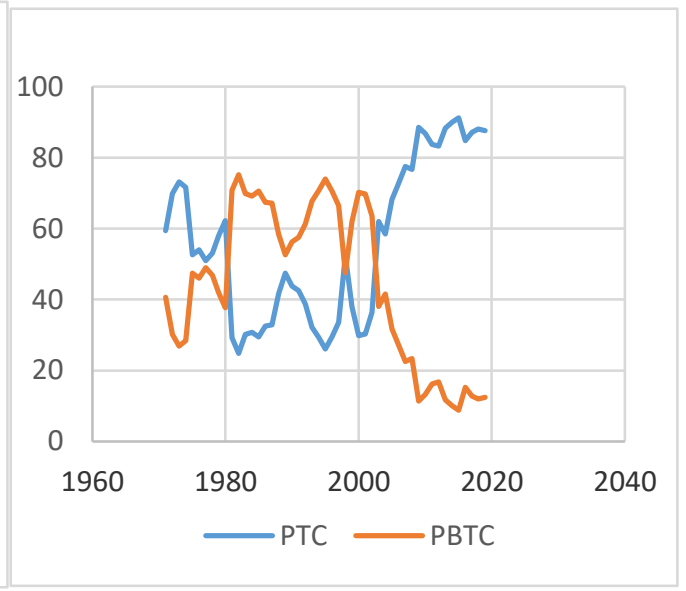

In the case of Mining and Quarrying the share of public investment shows varying but generally rising trend till 1987 (with the maximum value of 96.1\%) then generally falling till 2000 and then a huge increase to $60.7 \%$ in 2001 . Later on, it decreased again till 2009 (reaching the least value of 13.9\%) and then increasing again and depicting huge variations in the last four years. The behavior of private investment is reverse of it in terms of growth and fall. In 2019 the share of public investment is approximately $61 \%$ and that of public investment is approximately $39 \%$ of total investment in this sector.Similarly, PI and PBI in the sector of Transport and Communication show cyclical type of relationship till 2003 
with starting shares of 59.45 and 40.6 percent of private and public investment, respectively. After 2003 private investment in general shows an increasing trend with little variations reaching the share of $86.6 \%$ and public investment a reverse trend reaching the share of $12.4 \%$. So, at present share of private investment is far higher than public investment.

The share of PI and PBI in the Construction sector indicates huge variations over the sampled period. In 1971 the share of the private sector was just 0.39 percent only compared to 99.61 percent of public investment. The share of PBI reached the minimum of 16.4 percent in 2001 then rising to $52.9 \%$ till 2013 and then falling to $7 \%$ in 2019. As Figure 3.4 shows, the share of private investment after 1992 increased the share of public investment and remained higher than it except in 2013.

In the Agriculture sector (Figure 3.5) share of public investment varied between a minimum of 0.013 and a maximum of 32.18 percent in 1996. In general, throughout the spanned period share of private investment remained much higher than public investment.

Figure 3.4: The share of Public and Private Investment in Construction

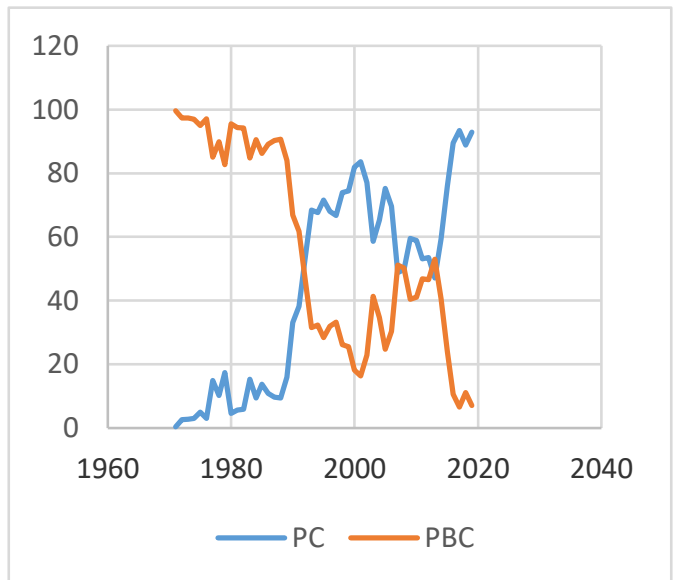

Figure 3.5: The share of Public and Private Investment in Agriculture

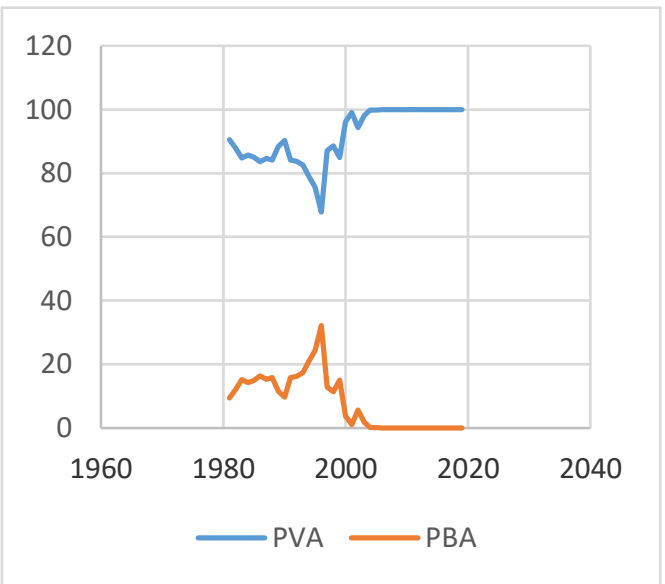

In both the sectors of Manufacturing and Finance, in general, the share of private investment remained much higher than the share of public investment except for 1976-81 where the share of public investment was more than private investment in case of Manufacturing and 2000-03 where public investment in the Finance sector was more than $10 \%$. 
Figure 3.6: The share of Public and Private investment in Manufacturing

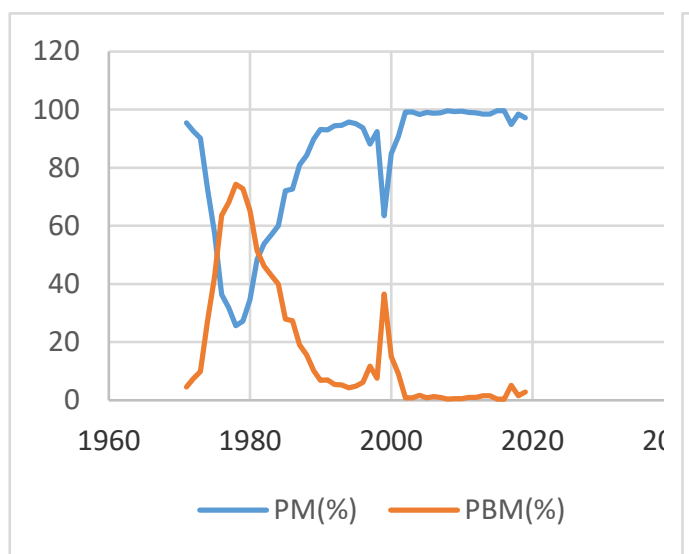

Figure 3.7: The share of Public and Private investment in Finance

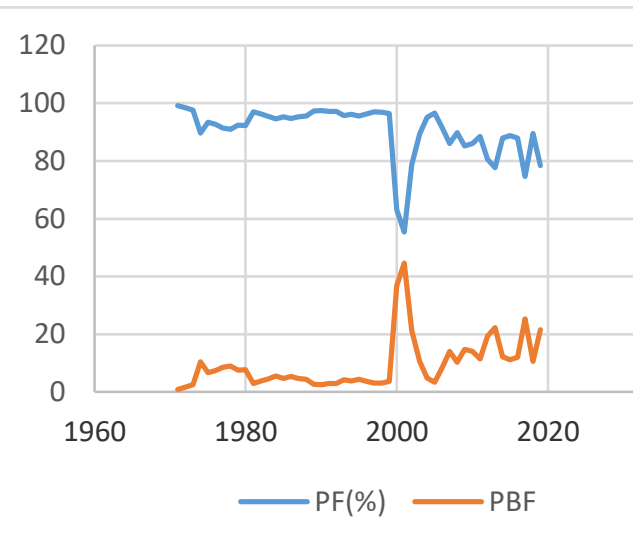

\section{Preliminary Findings, Results and Discussion}

The descriptive statistics including mean, standard deviation, minimum and maximum value of each variable are given in Table 4.1.

Table 4.1: Descriptive Statistics

\begin{tabular}{lcclll}
\hline Variables & $\begin{array}{c}\text { Number of } \\
\text { Observation }\end{array}$ & Mean & $\begin{array}{l}\text { Standard } \\
\text { Deviation }\end{array}$ & Min & Max \\
\hline Interest rate (\%) & 49 & 8.601 & 2.377 & 2.140 & 12.470 \\
Log Output & 49 & 14.374 & 1.981 & 10.829 & 17.452 \\
& & & & & \\
Debt to GDP (\%) & 49 & 71.591 & 2.474 & 51.970 & 101.73 \\
Log of Overall Public Investment & 49 & 10.910 & 1.353 & 7.755 & 12.759 \\
& & & & & \\
\hline Sector-wise Public Investment (Log) & & & & & \\
\hline Transport and Communication & 49 & 9.433 & 1.747 & 5.568 & 11.356 \\
Mining and Quarrying & 49 & 7.742 & 2.376 & 1.945 & 11.043 \\
Manufacturing & 49 & 8.019 & 1.228 & 4.219 & 10.448 \\
Finance & 49 & 6.811 & 1.801 & 1.609 & 9.737 \\
Construction & 49 & 8.203 & 0.848 & 6.331 & 9.899 \\
Agriculture & 39 & 6.458 & 1.693 & 3.784 & 9.160 \\
Log of Overall Private investment & 49 & 11.918 & 2.234 & 8.169 & 15.149 \\
& & & & & \\
\hline Sector-wise Private investment (Log) & & & & & \\
\hline Transport and Communication & 49 & 9.768 & 2.256 & 6.249 & 13.201 \\
$\quad$ Mining and Quarrying & 49 & 7.181 & 3.046 & 2.890 & 11.415 \\
$\quad$ Manufacturing & 49 & 10.556 & 2.063 & 6.926 & 13.196 \\
$\quad$ Finance & 49 & 9.409 & 1.398 & 6.234 & 11.016 \\
Construction & 49 & 7.656 & 2.519 & 1.386 & 11.319 \\
$\quad$ Agriculture & 39 & 11.128 & 1.800 & 8.494 & 13.953 \\
\hline
\end{tabular}


For all sectors except the Agriculture sector, data span from 1971 to 2019. However, in the case of the Agriculture sector, the data utilized starts in 1981 due to the non-availability of prior data from published sources. Therefore, we have only 39 observations available for the Agriculture sector. The mean value of the interest rate is $8.601 \%$ which shows the high cost of borrowing for investment. Further, the maximum value of the interest rate is also very high. Further, the average value of debt to GDP is $71.6 \%$ due to the high volume of both domestic and foreign debt. Among control variables, the highest dispersion was observed for the debt to GDP.

Further, when we compared public investment and private investment in different sectors, the highest mean value of public investment is realized for the sector of Transport and Communication and the lowest is observed for the sector of Agriculture, while the average value of private investment is the highest in case of Agriculture sector and the lowest in Mining and Quarrying sector. Regarding standard deviation, the highest dispersion in public investment is apparent in Mining and Quarrying and lowest in Construction. However, in the case of private investment highest variability is observed in Mining and Quarrying and the lowest in the Finance sector.

The Augmented Dicky Fuller (ADF) test results for testing the stationarity of variables included in the study are reported in table 4.2. where "i" indicates intercept and " $\mathrm{i}+\mathrm{t}$ ", indicates intercept and trend. Unit root analysis shows that at a level all variables are non-stationary but at first difference the concerned variables become stationary.

Table 4.2: Unit Root Test

\begin{tabular}{|c|c|c|c|c|c|}
\hline \multirow[t]{2}{*}{ Variable } & \multirow[t]{2}{*}{ Symbol } & \multicolumn{2}{|c|}{ Level } & \multicolumn{2}{|c|}{$\mathbf{1}^{\text {st }}$ Difference } \\
\hline & & $\mathrm{ADF}(\mathrm{i})$ & $\mathrm{ADF}(\mathrm{i}+\mathrm{t})$ & $\mathrm{ADF}(\mathrm{i})$ & $\mathrm{ADF}(\mathrm{i}+\mathrm{t})$ \\
\hline Interest rate & $I$ & -2.624 & -3.374 & $-5.669 * * *$ & $-5.598 * * *$ \\
\hline Output & Lgdp & -2.474 & -1.646 & $-5.673 * * *$ & $-6.559 * * *$ \\
\hline Debt to GDP & Dtgdp & -2.446 & -2.444 & $-8.536^{* * *}$ & $-8.609 * * *$ \\
\hline Public investment Overall & $\mathrm{Lpb}$ & -2.167 & -2.460 & $-7.338 * * *$ & $-7.788 * * *$ \\
\hline Sector-Wise Public Investment & & & & & \\
\hline Transport and communication & Lpbtc & -1.874 & -1.754 & $-7.461 * * *$ & $-7.831 * * *$ \\
\hline Mining and quarrying & Lpbmq & -2.664 & -2.487 & $-10.429 * * *$ & $-10.858 * * *$ \\
\hline Manufacturing & Lpbm & -2.058 & -2.185 & $--3.336 * *$ & $-3.376^{* * *}$ \\
\hline Finance & Lpbf & -0.824 & -2.664 & $-4.931 * * *$ & $-5.223 * * *$ \\
\hline Construction & Lpbc & -2.443 & -2.518 & $-7.172 * * *$ & $-7.152 * * *$ \\
\hline Agriculture & Lpba & -1.288 & -1.81 & $-7.126^{* * *}$ & $-7.018 * * *$ \\
\hline Private investment Overall & Lpv & -1.206 & -1.174 & $-7.179 * * *$ & $-7.425 * * *$ \\
\hline Sector-wise Private investment & & & & & \\
\hline Transport and communication & Lptc & -0.419 & -2.929 & $-5.235^{* * *}$ & $-5.177 * * *$ \\
\hline Mining and quarrying & Lpmq & -0.889 & -1.295 & $-8.033 * * *$ & $-8.028 * * *$ \\
\hline Manufacturing & Lpm & -2.336 & -0.820 & $-5.989 * * *$ & $-7.666^{* *}$ \\
\hline Finance & Lpf & -2.019 & -2.861 & $-5.990 * * *$ & $-6.163 * * *$ \\
\hline Construction & $\mathrm{Lpc}$ & -2.443 & -3.248 & $-9.594 * * *$ & $-9.575^{* * *}$ \\
\hline Agriculture & Lpa & -0.023 & -1.818 & $-5.473 * * *$ & $-5.418 * * *$ \\
\hline
\end{tabular}


As all the variables used in this study are integrated of the same order I (1) so indicate the possibility of cointegration capturing the long-run relationship. These results are consistent with the studies of Oriavwote and Oyovwi (2014); Saeed 2006; Bose and Haque (2005); Kustepeli (2005), Monadjemi and Huh (1998), Rossiter (2002).

The optimal lag length for estimation of the VAR model which is a prerequisite for applying Johansen Cointegration is presented in Table 4.3. The VAR model is estimated for 1 to 4 lags for annual data. We used the Schwartz criteria for optimal lag selection. In general, Schwartz criteria supports the optimal lag length of 1 for cointegration models except for the sector of Agriculture with an optimal lag length of 2 .

Table 4.3: Lag Selection through Schwartz Criteria

\begin{tabular}{lcccccc}
\hline Sectors & Lags & $\mathbf{0}$ & $\mathbf{1}$ & $\mathbf{2}$ & $\mathbf{3}$ & $\mathbf{4}$ \\
\hline Aggregate level & SC & -0.804 & $-1.903^{*}$ & -1.732 & -1.520 & -1.425 \\
Transport and Communication & SC & 2.447 & $0.966^{*}$ & 0.982 & 1.229 & 1.338 \\
Mining and Quarrying & SC & 4.953 & $3.775^{*}$ & 3.987 & 4.285 & 4.432 \\
Manufacturing & SC & 3.176 & $1.670^{*}$ & 2.001 & 2.208 & 2.505 \\
Finance & SC & 3.122 & $2.356^{*}$ & 2.526 & 2.643 & 2.877 \\
Construction & SC & 3.492 & $2.341^{*}$ & 2.669 & 2.852 & 2.712 \\
Agriculture & SC & 2.138 & 1.482 & $1.251^{*}$ & 1.332 & 1.551 \\
\hline
\end{tabular}

Johansen co-integration test results showing the existence of long-run association among variables are given in table 4.4. Mostly the Trace statistics and Maximum Eigen statistics show the same results but in some cases, these results differ. However, Trace statistics is preferred because it produces more accurate results as compared to Maximum Eigen statistics. (Asari et al., 2011; Rashid, 2006). In our analysis, we are using one cointegration vector despite two co-integrating vectors, because the highest Eigenvalue is associated with the first Cointegration equation and it also relates to the stationarity of the variables. (Oriavwote \& Oyovwi, 2014; Rashid, 2009).

Table 4.4: Johansen Co-integration Test Results

\begin{tabular}{lcc}
\hline & $\begin{array}{c}\text { Trace Statistics } \\
\text { (Co-integrating Vectors) }\end{array}$ & $\begin{array}{c}\text { Max-Eigenvalue } \\
\text { (Co-integrating Vectors) }\end{array}$ \\
\hline Aggregate Level & 2 & 2 \\
Transport and Communication & 2 & No \\
Mining and Quarrying & 1 & 1 \\
Manufacturing Sector & 2 & 2 \\
Finance Sector & 1 & 2 \\
Construction & 1 & 1 \\
Agriculture & 1 & 1 \\
\hline
\end{tabular}


In table 4.5 normalized cointegration coefficients representing the long-run relationship between public and private investment are reported. These results indicate a long run complementary type association among public and private investments at the aggregate level and in almost all the sectors except the sectors of Finance. This result is consistent with literature such as Gjini and Kukeli (2012), Ang (2009), Hatano (2010), Erden and Holcombe (2006), Rashid (2006), Mitra (2006), Naqvi (2002), Hassan, Othman, and Karim (2011), Pereira (2001), Mittnik and Neumann (2001), Monadjemi and Huh (1998), and Erenburg (1993). Our results in general support the accelerator theory of investment which indicates that the increase in growth because of public investment further attracts investors to invest by enhancing their confidence in the economy and thus, private investment increases.

Table 4.5: Normalized Cointegration Coefficient

\begin{tabular}{lccc}
\hline Sectors & PI & PRI & Log-Likelihood \\
\hline Aggregate Level & 1.000 & $2.636^{*}$ & 61.178 \\
Transport and & 1.000 & $(0.570)$ & 0.884 \\
Communication & 1.000 & $0.305^{*}$ & -53.576 \\
Mining and Quarrying & 1.000 & $3.832^{*}$ & -22.134 \\
Manufacturing Sector & 1.000 & $(0.890)$ & -39.702 \\
Finance Sector & 1.000 & $(0.196)$ & -14.472 \\
Construction & 1.000 & $-3.030^{*}$ & -1.484 \\
Agriculture & & $0.984^{*}$ & $(0.332)$ \\
\hline
\end{tabular}

For the short-run effect, Figure 4.1 presents the results of the impulse response function, showing the effect of one standard deviation shock in public investment at the aggregate and sectoral level on relevant private investment at the aggregate and sectoral level.

At the aggregate level, one standard deviation shock to public investment shows that the entire confidence interval is above zero and in the short-run fluctuating pattern exists but in the medium to long run decreasing pattern is observed. The overall relationship is still positive and significant because the confidence interval does not intersect the zero line. This means it supports the crowding-in effect. At the sectoral level, all the sectors show crowding in effect except the sector of Transport and Communication and the Agriculture sector where the confidence interval in both sectors intersect the zero line that is why it is insignificant. 
Figure 4.5: Impulse Response Function (IRF) Results

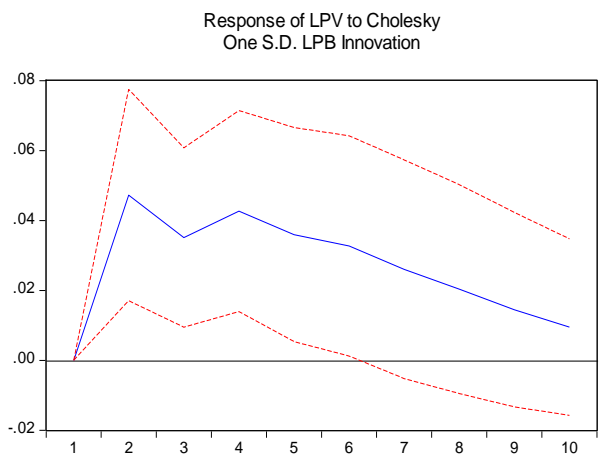

At Aggregate Level

Response of LPMQ to Cholesky One S.D. LPBMQ Innovation

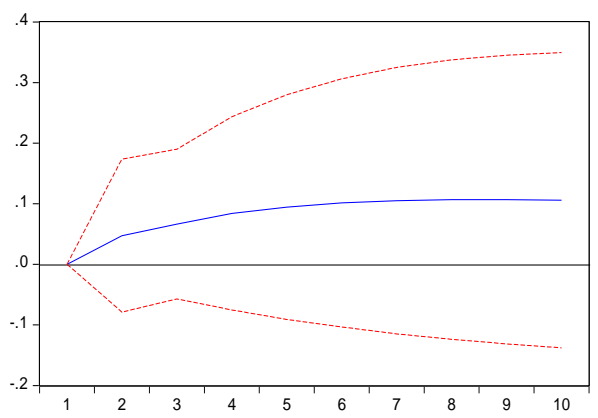

Mining and Quarrying sector

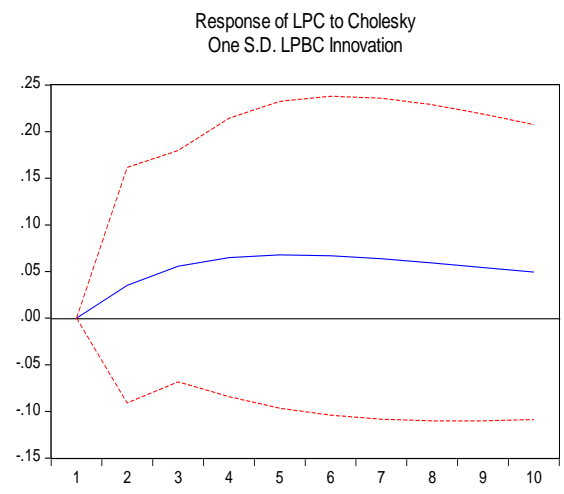

Construction Sector

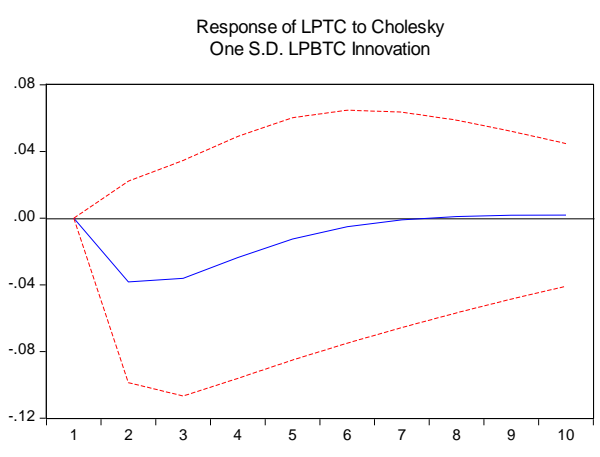

Transport and Communication sector

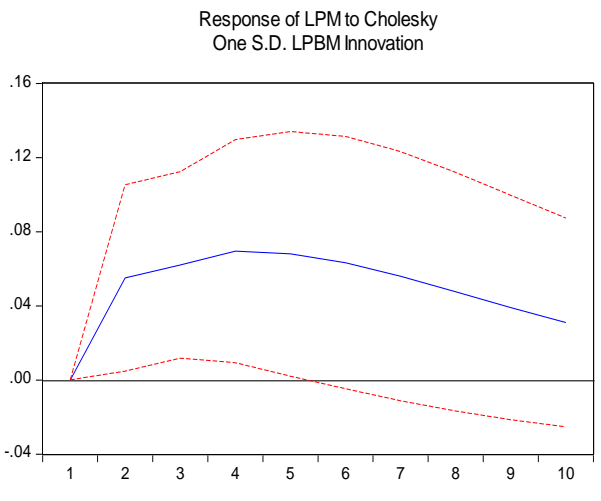

Manufacturing Sector

Response of LPF to Cholesky One S.D. LPBF Innovation

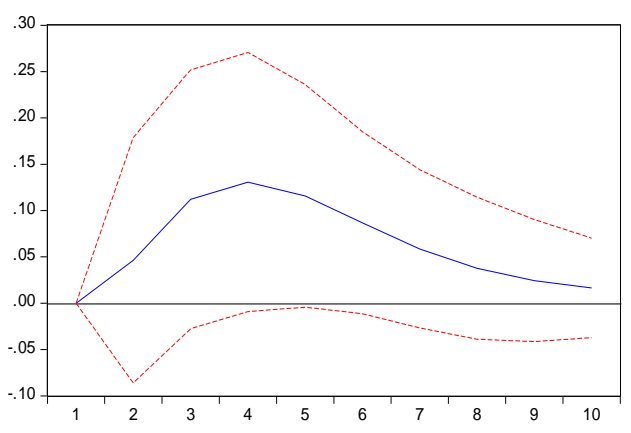

Finance Sector 


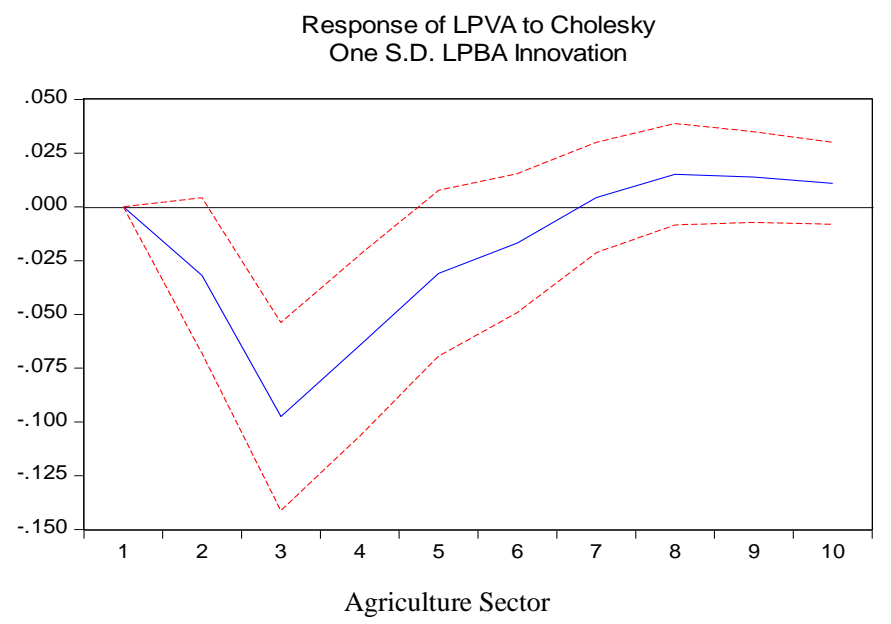

Moreover, in Transport and Communication sector and Agriculture sector the short-run response is negative because the confidence interval is below the zero lines but in long run, the confidence interval intersects the zero line and in the agriculture sector the confidence interval turns positive but the overall effect is insignificant. The results, in general, support the crowding-in effect which is consistent with (Afonso \& Aubyn, 2008; Monadjemi \& Huh, 1998; Rashid, 2006; $\mathrm{Xu} \&$ Yan, 2014). This channel of public investment crowding in private investment indicates that initially, private investors can be hesitant due to uncertainty and risk, but more public investment and externalities associated with it facilitate and encourage the confidence of private investors. PI not only crowds in PRI but may also enhance its productivity (Hyder \& Ahmed, 2004).

The results of the Vector Error Correction Model are shown in Table 4.6. The error correction term, EC (-1), is inversely significant at the aggregate level and across four sectors including Mining and Quarrying, Manufacturing, Finance and Construction which means that there exists a significant long-run association among public and private investment. The significant value of the coefficient of error correction term with a negative sign indicates that a short-term variation will lead to establishing a long-run relationship among variables.

The results of the study reveal that there is the existence of the short-run association in four sectors and at the aggregate level. The sectoral analysis shows that the speed of convergence was the highest in the Construction sector and the lowest speed of convergence was observed at the aggregate level. 
Table 4.6: Vector Error Correction (VEC) Model

\begin{tabular}{|c|c|c|c|}
\hline Sectors & EC(-1) & $\mathbf{F}$ & $\overline{\mathbf{R}^{2}}$ \\
\hline Aggregate Level & $\begin{array}{c}-0.005 * * \\
(0.002)\end{array}$ & 4.689 & 0.582 \\
\hline $\mathrm{C}$ & $\begin{array}{l}0.250 \\
(0.081)\end{array}$ & & \\
\hline Dlpdtgdp & $\begin{array}{l}-0.829 * * * \\
(0.235)\end{array}$ & & \\
\hline Di & $\begin{array}{c}-0.019 * * \\
(0.009)\end{array}$ & & \\
\hline Dlgdp & $\begin{array}{c}0.427 * * \\
(0.171)\end{array}$ & & \\
\hline Transport and Communication & $\begin{array}{c}-0.022 \\
(0.016)\end{array}$ & 3.645 & 0.396 \\
\hline $\mathrm{C}$ & $\begin{array}{c}0.261 \\
(0.149)\end{array}$ & & \\
\hline Dlpdtgdp & $\begin{array}{c}-0.721 * * \\
(0.313)\end{array}$ & & \\
\hline Di & $\begin{array}{c}0.014 \\
(0.018)\end{array}$ & & \\
\hline Dlgdp & $\begin{array}{c}0.985 * * \\
(0.494)\end{array}$ & & \\
\hline Mining and Quarrying & $\begin{array}{c}-0.028 * \\
(0.010)\end{array}$ & 5.245 & 0.345 \\
\hline $\mathrm{C}$ & $\begin{array}{r}0.252 \\
(-0.296)\end{array}$ & & \\
\hline Dlpdtgdp & $\begin{array}{c}-0.054 * * \\
(0.027)\end{array}$ & & \\
\hline Di & $\begin{array}{r}-0.009 \\
(0.043)\end{array}$ & & \\
\hline Dlgdp & $\begin{array}{l}0.531 \\
(2.102)\end{array}$ & & \\
\hline Manufacturing & $\begin{array}{c}-0.009 * * \\
(0.003)\end{array}$ & 5.163 & 0.427 \\
\hline $\mathrm{C}$ & $\begin{array}{l}-0.095 \\
(0.097)\end{array}$ & & \\
\hline Dlpdtgdp & $\begin{array}{l}-0.034 * * \\
(0.015)\end{array}$ & & \\
\hline Di & $\begin{array}{l}-0.032 * * \\
(0.013)\end{array}$ & & \\
\hline Dlgdp & $\begin{array}{c}1.507 \\
(0.658)^{* *}\end{array}$ & & \\
\hline Finance & $\begin{array}{c}-0.078 * * * \\
(0.028)\end{array}$ & 4.713 & 0.427 \\
\hline $\mathrm{C}$ & $\begin{array}{l}0.847 \\
(0.259)\end{array}$ & & \\
\hline Dlpdtgdp & $\begin{array}{l}-1.206 \\
(1.080)\end{array}$ & & \\
\hline Di & $\begin{array}{c}-0.039 * * \\
(0.017)\end{array}$ & & \\
\hline Dlgdp & $\begin{array}{l}5.713^{*} \\
(2.010)\end{array}$ & & \\
\hline Construction & $\begin{array}{c}-0.096^{* *} \\
(0.048)\end{array}$ & 3.882 & 0.22 \\
\hline $\mathrm{C}$ & $\begin{array}{c}0.237 \\
(0.280)\end{array}$ & & \\
\hline
\end{tabular}




\begin{tabular}{lccc} 
Dlpdtgdp & -0.222 & & \\
& $(1.070)$ & & \\
Di & 0.056 & & \\
& $(0.037)$ & & \\
Dlgdp & -0.081 & & \\
& $(1.937)$ & & \\
Agriculture & -0.013 & & \\
& $(0.014)$ & & \\
Dlpdtgdp & -0.488 & & \\
& $(0.426)$ & \\
Di & -0.007 & \\
& $(0.014)$ & \\
Dlgdp & 1.542 & \\
& $(0.726)^{*}$ \\
\hline
\end{tabular}

Note: In parenthesis are the values of standard error. $* * *, * *, *$ indicate significance at $1 \%, 5 \%$ and $10 \%$ level of significance.

Regarding the control variable, the variable of debt as a percentage of GDP has a significant adverse effect on private investment at an aggregate level and in the sectors of Mining \& Quarrying, Manufacturing and Transport \& Communication while it has an insignificant effect on the rest of the sectors. This negative effect indicates that the higher debt service payments associated with a large external debt reduce the funds available for investment. Further, high levels of existing debt reduce the incentives for further investment, because much of the forthcoming returns from the investment must be used to repay existing debt and therefore acts as a tax on domestic investment (Borensztein, 1990; Froot \& Krugman, 1990).

The control variable of GDP which is used as a proxy for overall or aggregate demand has a significant positive effect on private investment at the aggregate level and at the sectoral level, this positive effect is statistically significant in Manufacturing, Finance, Transport and Communication, and Agriculture.

The control variable of interest rate proxying financing cost to invest has a significant negative effect on aggregate private investment and private investment in the sectors of Manufacturing and Finance. For the remaining sectors, the effect of interest rate is generally negative but insignificant.

\section{Conclusion}

The results of this study obtained through the Johansen Cointegration and VECM show that at the aggregate level public investment complements private investment in the long run. Likewise, at the sectoral level, our results generally support that public investment crowds in private investment in the long run 
excluding the sector of Finance, where crowding out of private investment was observed.

The short-run dynamics observed through impulse response function remained consistent with long-run analysis at the aggregate level and in four sectors including Mining and Quarrying, Manufacturing, Finance and Construction. In the Transport \& Communication sector and Agriculture sector, the short-run relationship between public and private investment was insignificant.

The share wise figures indicate that the share of public investment in total investment was generally declining at the aggregate level and sectoral level. The general crowding in private investment shown by our results may be the result of welfare benefits with positive externalities arising from public investment (Romer, 1986). There are four types of public investment: infrastructure, human capital, $R$ \& D investment, and business investment. Primarily, as already mentioned public investment can lead to more output which in turn generates more physical and financial resources in the economy. Additionally, public spending on infrastructures such as roads, railroads, highways, sewage, education, power plants and water systems often lowers private-sector costs. Such type of infrastructure investment by the public sector complements private investment and improves private capital productivity. The crowding out observed in the Finance sector seems to indicate that the public and private investors compete for the joint ventures.

Further, the nature of both types of investment is mainly different. Private investment is primarily undertaken for profit-seeking purposes. However, public investment is generally for the welfare and development of the country like investment in physical and social infrastructure. However, private investors may not participate normally in long term and risky projects (useful for the country) but the government does undertake such projects for the reason that such projects are generally required for long term growth of the economy. So, our results and generally declining share of public investment highlight that the government is playing its role as an "enabler" (or facilitator) of private investment in terms of association between public and private investment. 


\section{References}

Al-Majali, A. A. (2018). Crowding out effect of public borrowing: The case of Jordan. International Review of Management and Marketing, 8(1), 119125 .

Afonso, A., \& Aubyn, M. (2008). Macroeconomic rates of return of public and private investment crowding in and crowding out effects. European Central Bank, Working Paper ,864.

Ahmad, I., \& Qayyum, A. (2008). Dynamic modeling of private investment in the agricultural sector of Pakistan. The Pakistan Development Review, 47(4), 517-530.

Al-Majali, A. A. (2018). Crowding out effect of public borrowing: The case of Jordan. International Review of Management and Marketing, 8(1), 119-125.

Ang, J. B. (2009). Do public investment and FDI crowd in or crowd out private domestic investment in Malaysia? Applied Economics, 41(7), 913-919.

Arrow, K. (1962). The economic consequences of learning by doing. Review of Economic Studies, 29(3), 155-173.

Asari, F., Baharuddin, N. S., Jusoh, N., Mohamad, Z., Shamsudin, N., \& Jusoff, K. (2011). A Vector Error Correction Model (VECM) approach in explaining the relationship between interest rate and inflation towards exchange rate volatility in Malaysia. World Applied Sciences Journal, 12(3), 49-56.

Aschauer, D. A. (1989). Is public expenditure productive? Journal of Monetary Economics, 23(2), 177-200.

Barth, J. R. and Cordes, J. (1980). Substitutability, complementarity, and the impact of government spending on economic activity. Journal of Economics and Business, 32(3), 235-242.

Bahal, G., Raissi, M., \& Tulin, V. (2018). Crowding out or crowding in? Public and private investment in India. World Development, 109, 323-333.

Bajo-Rubio, O., \& Sosvilla-Rivero, S. (1993). Does public capital affect private sector performance? An analysis of the Spanish Case, 1964-1988. Economic Modelling, 10(3), 179-185.

Bell, S. (2000). Do taxes and bonds finance government spending? Journal of Economic Issues, 34(3), 603-620. 
Blejer, M., \& Khan, M. S. (1984). Private investment in developing countries. Finance and Development, 21(2), 26.

Borensztein, E. (1990). Debt overhang, credit rationing and investment. Journal of Development Economics, 32(2), 315-335.

Bose, N., \& Haque, M. E. (2005). Causality between public investment in transport and communication and economic growth. Journal of Economic Development, 30(1), 95-106.

Buiter, W. H. (1977). An integration of short-run Neo-Keynesian analysis and growth theory. De Economist, 125(3), 340-359.

Canh, N. T., \& Phong, N. A. (2018). Effect of public investment on private investment and economic growth: Evidence from Vietnam by economic industries. Applied Economics and Finance, 5(2), 95-110.

Cavallo, E., \& Daude, C. (2011). Public investment in developing countries: A blessing or a curse? Journal of Comparative Economics, 39(1), 65-81.

Clark, J. M. (1917). Business acceleration and the law of demand: A technical factor in economic cycles. Journal of Political Economy, 25(3), 217-235.

David, P. A., \& Scadding, J. L. (1974). Private savings: Ultrarationality, aggregation, and denison's law. Journal of Political Economy, 82(2), 225249.

Diamond, P. A. (1965). National debt in a Neoclassical growth model. The American Economic Review, 55(5), 1126-1150.

Dreger, C., \& Reimers, H. E. (2015). The impact of public investment on private investment in the Euro Area. Vierteljahrshefte zur Wirtschaftsforschung, 84(3), 183-193.

Emran, M. S., \& Farazi, S. (2009). Lazy banks? Government borrowing and private credit in developing countries. Institute for International Economic Policy Paper Series, 2009-9, 1-23.

Erden, L., \& Holcombe, R. G. (2005). The effects of public investment on private investment in developing economies. Public Finance Review, 33(5), 575602.

Erden, L., \& Holcombe, R. G. (2006). The linkage between public and private investment: A Co-integration analysis of a panel of developing countries. Eastern Economic Journal, 32(3), 479-492. 
Erenburg, S. J. (1993). The real effects of public investment on private investment. Applied Economics, 25(6), 831-837.

Erenburg, S. J., \& Wohar, M. E. (1995). Public and private investment: Are there causal linkages? Journal of Macroeconomics, 17(1), 1-30.

Fatima, G. (2012). Joint impact of investment (Public and Private) on the economic growth of Pakistan: Co-Integration approach. International Journal of Research in Management, Economics and Commerce, 2(9), 127-134.

Fournier, J. M. (2016). The positive effect of public investment on potential growth. OECD Economics Department, Working Papers, 1347.

Foye, V. (2014). The impact of public capital spending on private investment in Nigeria. Journal of International Academic Research for Multidisciplinary, 2(2), 86-100.

Froot, K., \& Krugman, P. (1990). Market based debt reduction for developing countries: Principles and prospects. The World Bank.

Fujii, T., Hiraga, K., \& Kozuka, M. (2013). Effects of public investment on sectoral private investment: A factor augmented VAR approach. Journal of the Japanese and International Economies, 27, 35-47.

Furceri, D., \& Sousa, R. M. (2011). The Impact of government spending on the private sector: Crowding out versus crowding in effects. Kyklos, 64(4), 516533.

Ghura, D., \& Goodwin, B. (2000). Determinants of private investment: A crossregional empirical investigation. Applied Economics, 32(14), 1819-1829.

Gjini, A., \& Kukeli, A. (2012). Crowding out effect of public investment an empirical investigation. Journal of Business and Economics Research, 10(5), 269-276.

Haque, N. U., \& Montiel, P. J. (1993). Fiscal adjustment in Pakistan: Some simulation results. Staff Papers, International Monetary Fund, 40(2), 471480 .

Hassan, S., Othman, Z., \& Karim, M. Z. A. (2011). Private and public investment in Malaysia: A panel time Series analysis. International Journal of Economics and Financial Issues, 1(4), 199-210.

Hatano, T. (2010). Crowding in effect of public investment on private investment. Ministry of Finance of Japan Public Policy Review, 6(1), 105-110. 
Hussain, A., Muhammad, S. D., Akram, K., \& Lal, I. (2009). Effectiveness of government expenditure crowding in or crowding out: Empirical evidence in case of Pakistan. European Journal of Economics, Finance and Administrative Sciences, 16, 136-142.

Hyder, K., \& Ahmed, Q. M. (2003). Why private investment in Pakistan has collapsed and how it can be restored. Lahore Journal of Economics, 9 (1), 107-128.

Hyder, K., \& Qayyum, A. (2001). Crowding out hypothesis in a Vector Error Correction framework: A case study of Pakistan. The Pakistan Development Review, 40(4), 633-650.

Jorgenson, D. W. (1971). Econometric studies of investment behavior: A survey. Journal of Economic Literature, 9(4), 1111-1147.

Keynes, J. M. (1936). The general theory of interest, employment and money. London, MacMillan.

Kollamparambil, U., \& Nicolaou, M. (2011). Nature and association of public and private investment: Public policy implications for South Africa. Journal of Economics and International Finance, 3(2), 98-108.

Koyck, L. M. (1954). Distributed lags and investment analysis. North-Holland Publishing Company, (4).

Kustepeli, Y. (2005). Effectiveness of fiscal spending: Crowding out and or crowding in? Yönetim ve Ekonomi, Celal Bayar Üniversitesi İktisadi ve İdari Bilimler Fakültesi Dergisi, 12(1), 184-192.

Laopodis, N. T. (2001). Effects of government spending on private investment. Applied Economics, 33(12), 1563-1577.

Looney, R. E. (1995). Public sector deficits and private investment: A test of the crowding Out hypothesis in Pakistan's manufacturing industry. The Pakistan Development Review, 34(3), 277-297.

Lucas Jr, R. E. (1988). On the mechanics of economic development. Journal of Monetary Economics, 22(1), 3-42.

Mahmoudzadeh, M., Sadeghi, S., \& Sadeghi, S. (2017). Fiscal spending and crowding out effect: A comparison between developed and developing countries. Institutions and Economies, 31-40. 
McKinnon, R., \& Shaw, E. (1973). Financial deepening in economic development. Washington, Brookings Institution.

Mitra, P. (2006). Has government investment crowded out private investment in India? The American Economic Review, 96(2), 337-341.

Mittnik, S., \& Neumann, T. (2001). Dynamic effects of public investment: Vector Autoregressive evidence from six industrialized countries. Empirical Economics, 26(2), 429-446.

Monadjemi, M. S., \& Huh, H. (1998). Private and government investment: A study of three OECD Countries. International Economic Journal, 12(2), 93-104.

Morrissey, O., \& Udomkerdmongkol, M. (2012). Governance, private investment and foreign direct investment in developing countries. World Development, 40(3), 437-445.

Munnell, A. H. (1992). Policy watch: Infrastructure investment and economic growth. The Journal of Economic Perspectives, 6(4), 189-198.

Naqvi, N. H. (2002). Crowding in or crowding out? Modeling the relationship between public and private fixed capital formation using Co-integration Analysis: The case of Pakistan 1964-2000. The Pakistan Development Review, 41(3), 255-275.

Oriavwote, V. E., \& Oyovwi, D. O. (2014). Interest rate and investment decision in Nigeria: A cointegration approach. American Journal of Business and Management, 3(1), 21-27.

Pereira, A. M. (2001). On the effects of public investment on private investment: What crowds in what? Public Finance Review, 29(1), 3-25.

Pesaran, M. H., \& Smith, R. P. (1998). Structural analysis of cointegrating VARs. Journal of Economic Surveys, 12(5), 471-505.

Phetsavong, K., \& Ichihashi, M. (2012). The impact of public and private investment on economic growth: Evidence from developing Asian countries. Instituto Brasileiro de Defesa do Consumidor, Discussion Paper Hiroshima University.

Ramirez, M. D. (1994). Public and private investment in Mexico, 1950-90: An empirical analysis. Southern Economic Journal, 61(1), 1-17.

Rashid, A. (2006). Public private investment linkage in Pakistan a multivariate cointegration analysis. South Asia Economic Journal, 7(2), 219-230. 
Rashid, A. (2009). Testing the modified combined PPP and UIP hypothesis in South Asian Economies. Applied Econometrics and International Development, 9(1), 199-218.

Romer, P. M. (1986). Increasing returns and long-run growth. Journal of Political Economy, 94(5), 1002-1037.

Romer, P. M. (1990). Capital, labor, and productivity. Brookings Papers on Economic Activity, Microeconomics, 337-367.

Rossiter, R. (2002). Structural cointegration analysis of private and public investment. International Journal of Business and Economics, 1(1), 59-67.

Saeed, N., Hyder, K., Ali, A., \& Ahmad, E. (2006). The impact of public investment on private investment: A disaggregated analysis. The Pakistan Development Review, 45(4), 639-663.

Saghir, R., \& Khan, A. (2012). Determinants of public and private investment an empirical study of Pakistan. International Journal of Business and science, 3(4), 183-188.

Seater, J. J. (1993). Ricardian equivalence. Journal of Economic Literature, 31(1), 142-190.

Serven, L. (1996). Does public capital crowd out private capital?Evidence from India. World Bank Publications, Available at: https://doi.org/10.1596/1813-9450-1613

Shafik, N. (1992). Modeling private investment in Egypt. Journal of Development Economics, 39(2), 263-277.

Solow, R. M. (1956). A contribution to the theory of economic growth. The Quarterly Journal of Economics, 70(1), 65-94.

Voss, G. M. (2002). Public and private investment in the United States and Canada. Economic Modelling, 19(4), 641-664.

Wai, U. T., \& Wong, C. h. (1982). Determinants of private investment in developing countries. The Journal of Development Studies, 19(1), 19-36.

Xu, X., \& Yan, Y. (2014). Does government investment crowd out private investment in China? Journal of Economic Policy Reform, 17(1), 1-12. 
Private and Public Investment Linkages:

Some Evidence Using Sectoral Level Data

\section{Appendix}

Public Investment

LPB
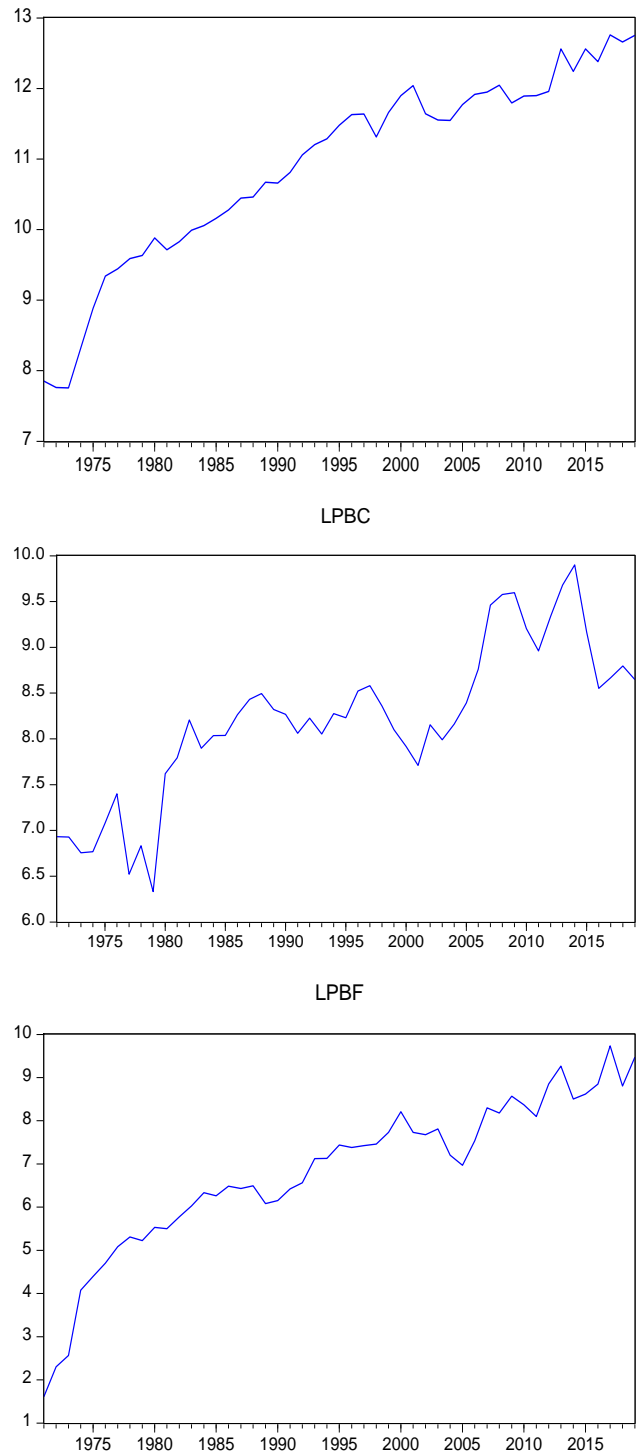

Private Investment

LPV
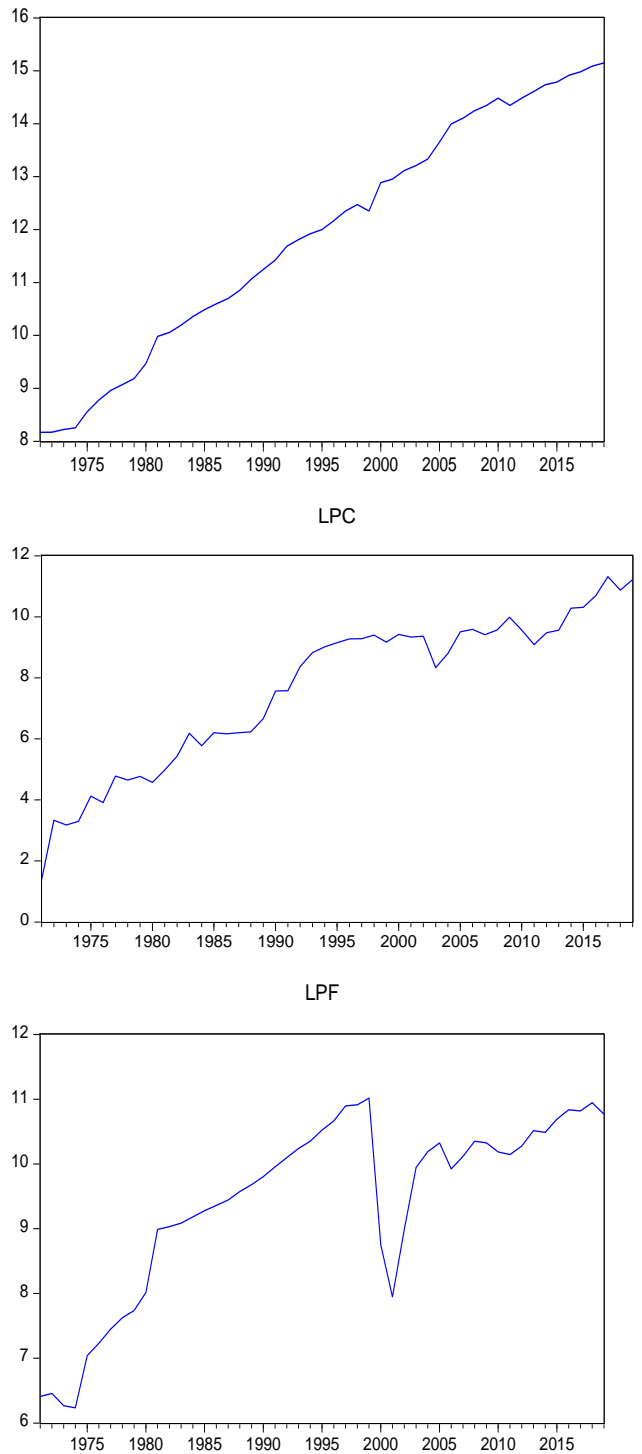
LPBM
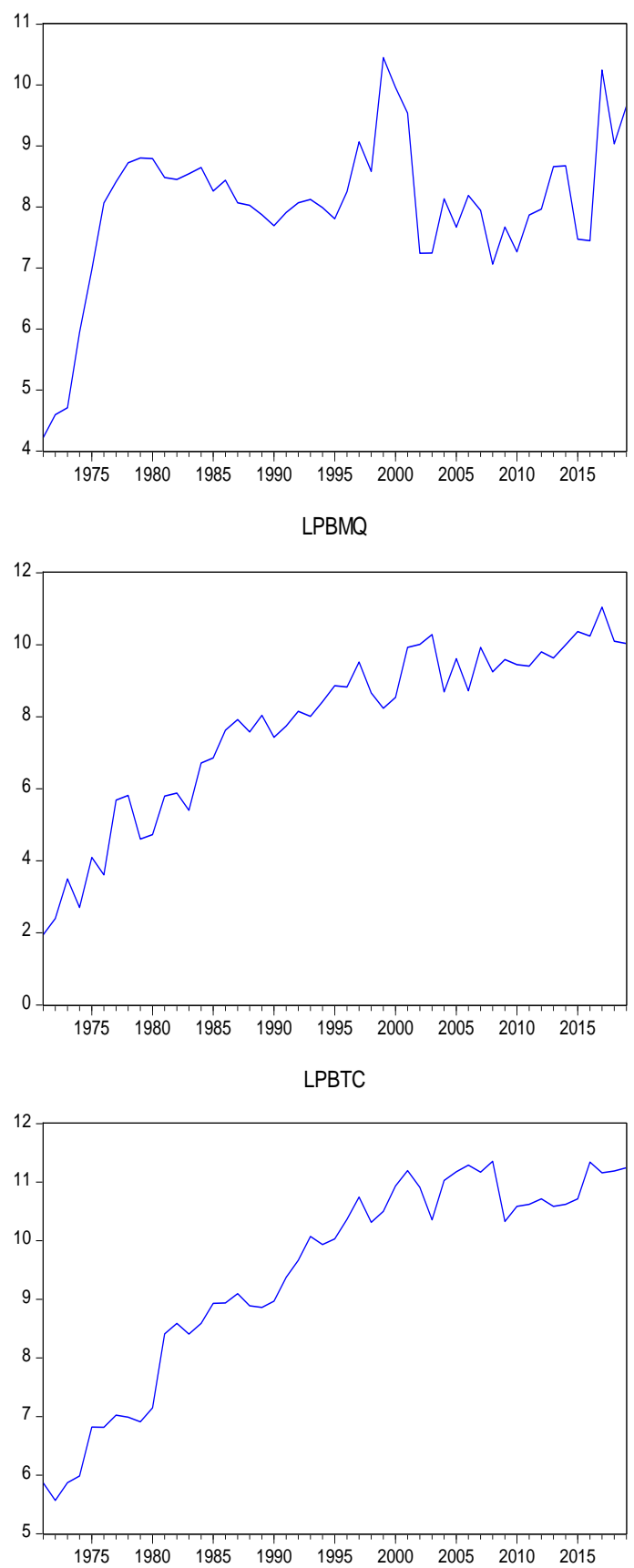

LPM
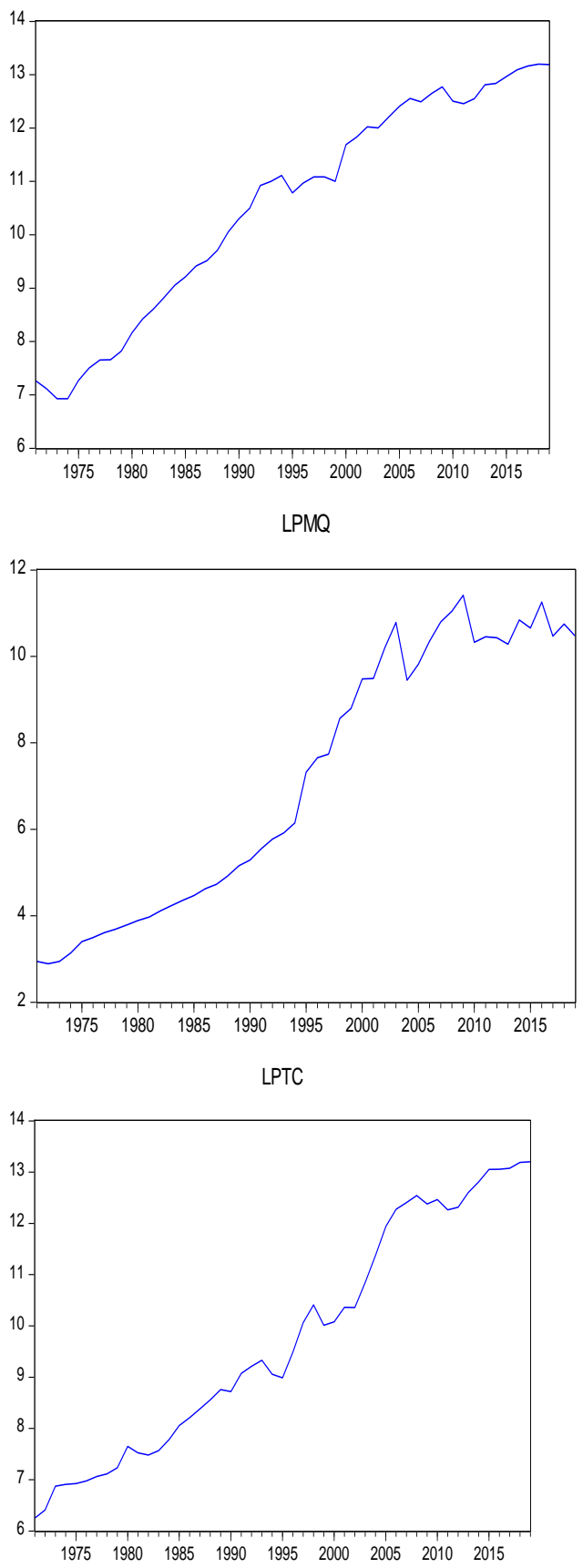
Private and Public Investment Linkages:

Some Evidence Using Sectoral Level Data

LPBA
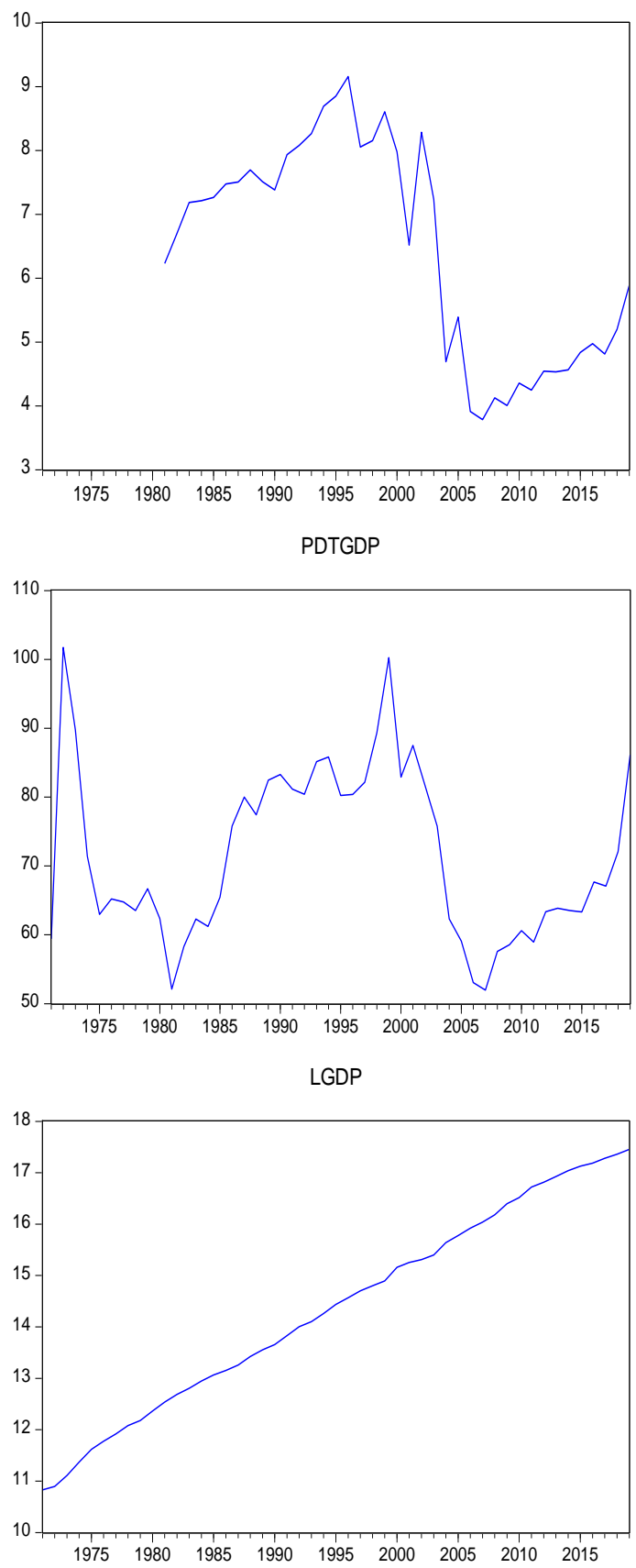

LPVA
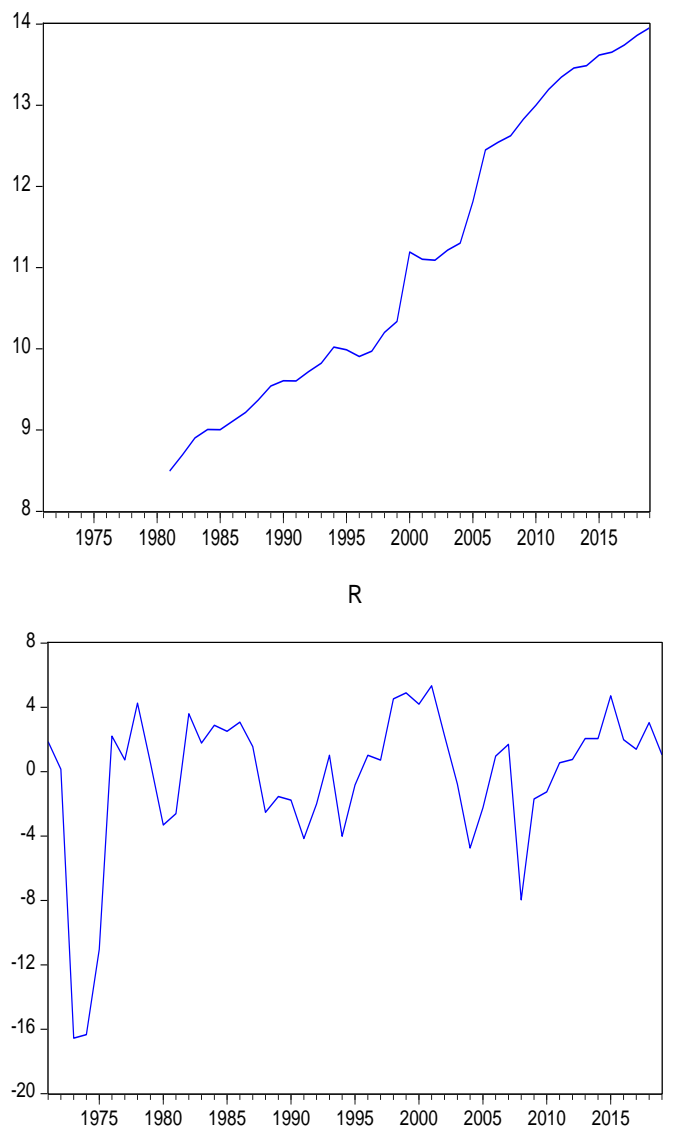